\begin{tabular}{|c|c|c|c|c|c|c|}
\hline \multirow{4}{*}{ Impact Factor: } & ISRA (India) & $=3.117$ & SIS (USA) & $=0.912$ & ICV (Poland) & $=6.630$ \\
\hline & ISI (Dubai, UAE & $=\mathbf{0 . 8 2 9}$ & РИНЦ (Russia & $=0.156$ & PIF (India) & $=1.940$ \\
\hline & GIF (Australia) & $=0.564$ & ESJI (KZ) & $=\mathbf{5 . 0 1 5}$ & IBI (India) & $=4.260$ \\
\hline & JIF & $=1.500$ & SJIF (Morocco & $=5.667$ & OAJI (USA) & $=0.350$ \\
\hline
\end{tabular}

SOI: $\underline{1.1 / \mathrm{TAS}} \quad$ DOI: $\underline{10.15863 / \mathrm{TAS}}$
International Scientific Journal
Theoretical \& Applied Science
$\begin{array}{ll}\text { p-ISSN: } 2308-4944 \text { (print) } & \text { e-ISSN: } 2409-0085 \text { (online) } \\ \text { Year: } 2019 \quad \text { Issue: } 01 \quad \text { volume: } 69 \\ \text { Published: } 30.01 .2019 \quad \underline{\text { http://T-Science.org }}\end{array}$

SECTION 25. Technologies of materials for the light and textile industry.
QR - Issue

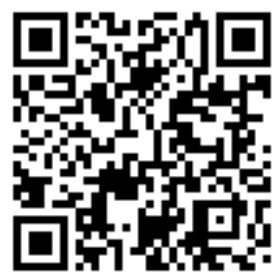

QR - Article

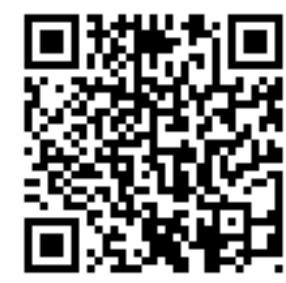

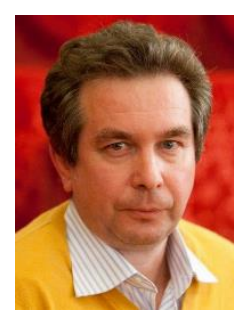
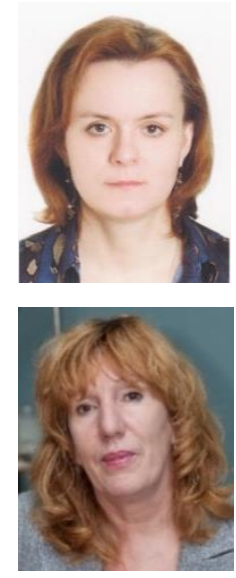

Elena Vladimirovna Kholodnova candidate of technical Sciences, Associate Professor Department of Artistic modelling, design and technology of garments The Kosygin State University of Russia (Kosygin University), professor of Orthodox St. Tikhon University of Humanities ev-xolodnova@yandex.ru

Andrei Vladimirovich Galkin graduate student, Department of Materials

Science and Commodity Examination The Kosygin State University of Russia (Kosygin University) galkin@softstitch.ru

Elena Anatolievna Chalenko candidate of technical Sciences,

Associate Professor Department of Artistic modelling, design and technology of garments The Kosygin State University of Russia (Kosygin University) ele-ela@yandex.ru

Elena Alexandrovna Kirsanova Phd, Professor, Department of Materials Science and Commodity Examination The Kosygin State University of Russia (Kosygin University) oimgudt@yandex.ru

\title{
DEVELOPMENT OF PARAMETERS FOR EMBROIDERY FINISHING ITEMS FOR LITURGICAL CLOTHES ON EMBROIDERY EQUIPMENT
}

Abstract: In article the factors influencing emersion of defects at performance of a machine embroidery pattern are observed. The parameters of clothing of orthodox clerics are established, recommendations are worked up for programming and elements of embroidery finishing.

Key words: finishing crosss, liturgical clothes, a floor under an embroidery pattern, contraction compensation.

Language: Russian

Citation: Kholodnova, E. V., Galkin, A. V., Chalenko, E. A., \& Kirsanova, E. A. (2019). Development of parameters for embroidery finishing items for liturgical clothes on embroidery equipment. ISJ Theoretical \& Applied Science, 01 (69), 268-275.

Soi: http://s-o-i.org/1.1/TAS-01-69-37 Doi: crossef https://dx.doi.org/10.15863/TAS.2019.01.69.37 


\begin{tabular}{|c|c|c|c|c|c|c|}
\hline \multirow{4}{*}{ Impact Factor: } & ISRA (India) & $=3.117$ & SIS (USA) & $=0.912$ & ICV (Poland) & $=6.630$ \\
\hline & ISI (Dubai, UAE & $=0.829$ & РИНЦ (Russia & $=0.156$ & PIF (India) & $=1.940$ \\
\hline & GIF (Australia) & $=0.564$ & ESJI (KZ) & $=\mathbf{5 . 0 1 5}$ & IBI (India) & $=4.260$ \\
\hline & JIF & $=1.500$ & SJIF (Morocco & $=5.667$ & OAJI (USA) & $=0.350$ \\
\hline
\end{tabular}

\section{РАЗРАБОТКА ПАРАМЕТРОВ ВЫШИВКИ ОТДЕЛОЧНЫХ ЭЛЕМЕНТОВ ДЛЯ БОГОСЛУЖЕБНЫХ ОБЛАЧЕНИЙ НА АВТОМАТИЗИРОВАННОМ ВЫШИВАЛЬНОМ ОБОРУДОВАНИИ}

Аннотация: В статье рассмотрены факторы, влияющие на появление дефектов при выполнении машинной выпивки. Установлены параметры и разработаны рекомендации для программирования и вышивания отделочных элементов на предметы одежды православных священнослужителей.

Ключевые слова: отделочные кресты, богослужебные облачения, настил под вышивку, компенсация стягивания.

Введение.

В наше время, когда восстанавливаются разрушенные храмы, которые в советский период были закрыты, возрастает спрос на предметы церковного текстиля и облачения священнослужителей. В связи с этим для декорирования часто используют автоматизированную вышивку, это позволяет сократить трудоемкость производства и стоимость изделия. Однако из-за этого, нередко страдает качество и художественный уровень предметов церковного убранства.

\section{Объекты и методы исследования.}

Машинная вышивка бывает свободноходовой, которая выполняется на универсальной швейной машине, заранее настроенной на определённый режим, или на швейной машине с компьютерным управлением. Процесс выполнения свободно-ходовой вышивки заключается в том, что оператор вручную перемещает пяльцы в разных направлениях и создаёт узор. Это требует от него наличия определённого опыта и навыка, чтобы рисунок правильно располагался на материале. Компьютерная вышивка осуществляется на вышивальном оборудовании с использованием специальных компьютерных программ, создаваемых проектировщиками. Работа такого оборудования полностью автоматизирована. Весь процесс состоит из нескольких этапов: разработка программы, настройка оборудования, подготовка ткани и вспомогательных материалов, и автоматизированного процесса вышивки.

Основными составляющими вышитых отделочных элементов (дизайнов) являются стежки, мотивы, строчки и застилы (рис.1). Стежок - это элемент вышивки между двумя последовательными проколами иглы. Мотив состоит из стежков, композиционно связанных в какой-либо узор и является самостоятельным модулем при проектировании вышивки. Частным случаем мотива является единичный стежок. Строчка - это линейно расположенный вышитый декор, состоящий из стежков и мотивов. Застилом является поверхностное заполнение поля вышивки стежками и мотивами [1].

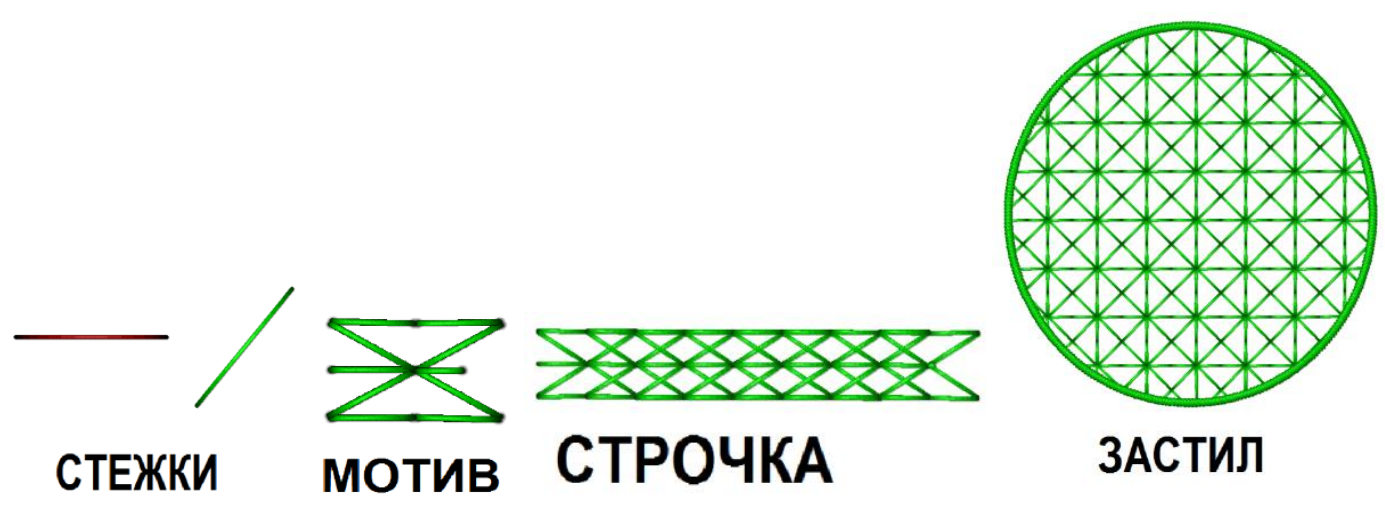

Рисунок 1. Элементы вышивки.

Результаты и обсуждение.

При изготовлении вышитых дизайнов машинным способом используют ограниченный ассортимент материалов. В основном, применяют синтетические, металлизированные или вискозные вышивальные нити с №40 [2]. Машинная технология накладывает ограничения на приёмы выполнения элементов вышивки, однако при этом можно достичь эффектов декорирования, имитирующие ручную вышивку. Например, в настоящее время становится популярной 3D-вышивка, аналогичная ручному шитью «по карте». Для реализации такой вышивки применяют объёмные прокладочные материалы. Несомненным достоинством машинной технологии служит наличие 


\begin{tabular}{|c|c|c|c|c|c|c|}
\hline \multirow{4}{*}{ Impact Factor: } & ISRA (India) & $=3.117$ & SIS (USA) & $=0.912$ & ICV (Poland) & $=6.630$ \\
\hline & ISI (Dubai, UAE & $=0.829$ & РИНЦ (Russia) & $=0.156$ & PIF (India) & $=1.940$ \\
\hline & GIF (Australia) & $=0.564$ & ESJI (KZ) & $=5.015$ & IBI (India) & $=4.260$ \\
\hline & JIF & $=1.500$ & SJIF (Morocco) & $=5.667$ & OAJI (USA) & $=0.350$ \\
\hline
\end{tabular}

возможности варьирования длины стежков и плотности заполнения застилов, что позволяет проектировать интересные художественные эффекты. Применение нескольких игловодителей в автоматизированной швейной машине расширяет колористический спектр при создании цветовых композиций.

Церковная вышивка тесно связана с такими областями искусства, как реставрация и реконструкция исторических памятников из текстиля. Прообразом богослужебных одеяний православного духовенства являются ветхозаветные одеяния Аарона и других священников, сделанными по непосредственному повелению Божию (Исх. 28, 2; 31, 10) и предназначенными только для священнослужения, для славы и благолепия Божественных служб. Они не могут быть носимы и употребляемы в быту [3], поэтому облачения духовенства и предметы убранства храмов имеют статичные формы и сюжеты дизайнов, которые подчинены требованиям церковной символики и традиций. Разрабатывая художественноконструктивные решения таких изделий, проектировщики старемятся добиваться соответствия их внешнего вида историческим прототипам [4].

На всех богослужебных облачениях христианского духовенства и предметах храмового интерьера согласно церковному канону должны присутствовать изображения крестов. Анализ сохранившихся памятников церковного шитья XIV-XIX веков свидетельствует, что до появления машинной вышивки кресты для предметов облачений изготавливали вручную, используя вышивку «по карте», вприкреп по настилу, вышивку жемчугом и камнями, технику аппликации. В период XIXXX веков кресты часто выполняют в технике золотной вышивки с использованием нитей канитель, «бить», а также применяют технологию плетения кружев из металлизированных нитей [5]. Обычно отделочные кресты изготавливали как отдельные элементы, которые пришивали на облачения. Это связано с затруднением выполнения вышивки на парчёвых тканях, которые имеют рыхлую структуру и обладают раздвигаемостью нитей на участках атласного переплетения.

Современные кресты для богослужебной одежды духовенства также изготавливают как отдельные элементы, которые в процессе изготовления соединяют с изделиями. Анализ ассортимента швейных изделий, которые используют в храмах Русской Православной Церкви показал, что размеры крестов стабильны для каждого предмета облачения, это связано с требованиями традиций к параметрам изделий и ширине галунов [6]. Размеры крестов варьируются в пределах от 4 см до 30 см. Кроме крестов в комплекты отделочных элементов входят кустодии - восьмиконечные звёзды и источники - полосы шириной $3 . .5$ см, нашиваемые по низу омофоров. Опытным и расчётным путями получены рекомендуемые размеры отделочных элементов для различных предметов облачений (таблица 1).

Таблица 1. Размеры отделочных элементов для различных предметов облачений и храмового убранства.

\begin{tabular}{|c|c|c|c|c|}
\hline $\begin{array}{c}\text { Наименование } \\
\text { изделия }\end{array}$ & $\begin{array}{l}\text { Вид отделочного } \\
\text { элемента }\end{array}$ & $\begin{array}{c}\text { Рекомендуемые } \\
\text { размеры, см }\end{array}$ & $\begin{array}{l}\text { Кол-во, } \\
\text { шт. }\end{array}$ & Примечания \\
\hline Саккос & Кустодия & $13 \ldots 16 \mathrm{~cm}$ & 1 & Стабильный размер \\
\hline \multirow{5}{*}{$\begin{array}{l}\text { Омофор } \\
\text { большой }\end{array}$} & Кустодия & От $12 \mathrm{~cm}$ & 1 & \multirow{10}{*}{$\begin{array}{c}\text { Зависят от ширины } \\
\text { изделия }\end{array}$} \\
\hline & Крест & От $12 \mathrm{~cm}$ & 4 & \\
\hline & $\begin{array}{l}\text { Источники (2 или } 3 \\
\text { ряда, одинаковой или }\end{array}$ & $\begin{array}{l}\text { Ширина } 3 \ldots .5 \text { см } \\
\text { Длина } 5 \ldots .8 \mathrm{~cm}\end{array}$ & 2 & \\
\hline & различной ширины) & $\begin{array}{l}\text { Ширина } 3 \ldots .5 \text { см } \\
\text { Длина } 8 \ldots .12 \text { см }\end{array}$ & 2 & \\
\hline & & $\begin{array}{l}\text { Ширина } 3 \ldots .5 \text { см } \\
\text { Длина } 12 \ldots .22 \text { см }\end{array}$ & 2 & \\
\hline \multirow[t]{5}{*}{ Омофор малый } & Кустодия & От $12 \mathrm{~cm}$ & 1 & \\
\hline & Крест & От $12 \mathrm{~cm}$ & 2 & \\
\hline & \multirow{3}{*}{$\begin{array}{l}\text { Источники (2 или } 3 \\
\text { ряда, одинаковой или } \\
\text { различной ширины) }\end{array}$} & $\begin{array}{l}\text { Ширина } 3 \ldots 5 \mathrm{~cm} \\
\text { Длина } 5 \ldots 8 \mathrm{~cm}\end{array}$ & 2 & \\
\hline & & $\begin{array}{l}\text { Ширина } 3 \ldots .5 \text { см } \\
\text { Длина } 8 \ldots .12 \text { см }\end{array}$ & 2 & \\
\hline & & $\begin{array}{l}\text { Ширина } 3 . .5 \text { см } \\
\text { Длина } 12 \ldots .22 \text { см }\end{array}$ & 2 & \\
\hline Сулок & Крест & $9 \ldots 11 \mathrm{~cm}$ & 1 & Стабильный размер \\
\hline
\end{tabular}




\begin{tabular}{|c|c|c|c|c|c|c|}
\hline \multirow{4}{*}{ Impact Factor: } & ISRA (India) & $=3.117$ & SIS (USA) & $=0.912$ & ICV (Poland) & $=6.630$ \\
\hline & ISI (Dubai, UAE & $=0.829$ & РИНЦ (Russia) & $=0.156$ & PIF (India) & $=1.940$ \\
\hline & GIF (Australia) & $=0.564$ & ESJI (KZ) & $=5.015$ & IBI (India) & $=4.260$ \\
\hline & JIF & $=1.500$ & SJIF (Morocco) & $=5.667$ & OAJI (USA) & $=0.350$ \\
\hline
\end{tabular}

\begin{tabular}{|c|c|c|c|c|}
\hline \multirow[t]{2}{*}{ Фелонь } & Кустодия & $14 \ldots 16 \mathrm{~cm}$ & 1 & \\
\hline & Крест & $14 \ldots 16 \mathrm{~cm}$ & 1 & \\
\hline \multirow[t]{2}{*}{ Епитрахиль } & Крест & $4 \ldots 5 \mathrm{~cm}$ & 1 & \\
\hline & & $9 \mathrm{~cm}$ & 6 & \\
\hline Палица & Крест & $12 \mathrm{~cm}$ & 1 & \\
\hline Набедренник & Крест & $12 \mathrm{~cm}$ & 1 & \\
\hline Пояс & Крест & $6 \ldots 7,5 \mathrm{~cm}$ & 1 & $\begin{array}{ccc}\text { Зависит } & \text { от } & \text { ширины } \\
\text { изделия } & \text { и } & \text { ширины } \\
\text { галунов } & & \\
\end{array}$ \\
\hline Поручи & Крест & $6 \ldots 8 \mathrm{~cm}$ & 1 & \multirow[t]{2}{*}{ Стабильный размер } \\
\hline $\begin{array}{l}\text { Подризник } \\
\text { (подсаккосник) }\end{array}$ & Крест & $8 \ldots 10 \mathrm{~cm}$ & 1 & \\
\hline $\begin{array}{l}\text { Сорочица } \\
\text { архиерейская }\end{array}$ & Крест & $8 \ldots 10 \mathrm{~cm}$ & 1 & \multirow[t]{2}{*}{ Стабильный размер } \\
\hline Стихарь & Крест & $14 \ldots 16 \mathrm{~cm}$ & 1 & \\
\hline $\begin{array}{l}\text { Орарь } \\
\text { одинарный }\end{array}$ & Крест & $6,5 \ldots 8 \mathrm{~cm}$ & 7 & \multirow{3}{*}{$\begin{array}{ccc}\text { Зависит } & \text { от } & \text { ширины } \\
\text { изделия } & \text { и } & \text { ширины } \\
\text { галунов } & & \end{array}$} \\
\hline $\begin{array}{l}\text { Орарь } \\
\text { иподиаконский }\end{array}$ & Крест & $6 \ldots 8 \mathrm{~cm}$ & 7 & \\
\hline \multirow[t]{2}{*}{ Орарь двойной } & Крест & $11 . .12 \mathrm{~cm}$ & 9 & \\
\hline & $\begin{array}{ll}\text { «Свят» } & \text { или } \\
\text { Херувимы } & \end{array}$ & $12 \ldots 15 \mathrm{~cm}$ & $3 \ldots 6$ & $\begin{array}{lr}\text { Зависит } & \text { от } \\
\text { изделия } & \text { ширины } \\
\text { расположения } & \text { вдоль } \\
\text { или поперёк. } \text { Элемент } \\
\text { может } & \text { заменять } \\
\text { кресты } & \text { или } \\
\text { отсутствовать } & \text { на } \\
\text { изделии } & \\
\end{array}$ \\
\hline Покровцы & Крест & $6 \ldots 9 \mathrm{~cm}$ & 2 & \multirow{2}{*}{$\begin{array}{l}\text { Зависит от размеров } \\
\text { изделия }\end{array}$} \\
\hline Воздух & Крест & $9 \ldots 12 \mathrm{~cm}$ & 1 & \\
\hline Пелена & Крест & $14 \ldots 16 \mathrm{~cm}$ & 1 & \multirow[t]{2}{*}{ Стабильный размер } \\
\hline Индития & Крест & $22 \ldots 26 \mathrm{~cm}$ & 1 & \\
\hline Аналойники & Крест & $9 \ldots 14 \mathrm{~cm}$ & 1 & $\begin{array}{l}\text { Зависит от размеров } \\
\text { изделия }\end{array}$ \\
\hline $\begin{array}{ll}\text { Покровы } & \text { на } \\
\text { литийный } & \\
\text { столик } & \end{array}$ & Крест & $9 \ldots 12 \mathrm{~cm}$ & 1 & Стабильный размер \\
\hline $\begin{array}{l}\text { Сорочица } \\
\text { Престол }\end{array}$ & Крест & $14 \ldots 26 \mathrm{~cm}$ & 1 & \multirow[t]{2}{*}{$\begin{array}{l}\text { Зависит от формы и } \\
\text { способа } \\
\text { креста }\end{array}$} \\
\hline Катапетасма & Крест & $14 \ldots 30 \mathrm{~cm}$ & 1 & \\
\hline $\begin{array}{l}\text { Хоругвь } \\
\text { (обратная } \\
\text { сторона) }\end{array}$ & Крест & $16 \ldots 20 \mathrm{~cm}$ & 1 & $\begin{array}{lr}\text { Традиционный } & \text { тип } \\
\text { изображения } \\
\text { Голгофа }\end{array}$ \\
\hline $\begin{array}{l}\text { Погребальный } \\
\text { покров }\end{array}$ & Крест & $14 \ldots 30 \mathrm{~cm}$ & 1 & $\begin{array}{l}\text { Зависит от формы и } \\
\text { способа выполнения } \\
\text { креста }\end{array}$ \\
\hline
\end{tabular}

Одним из распространённых дефектов машинной вышивки является стянутость материала и смещение элементов вышивки относительно своего запрограммированного положения (рис. 2). Устранение дефектов связано с введением настилов, программной компенсации стягивания, a также с применением вспомогательных материалов [7]. 


\begin{tabular}{|c|c|c|c|c|c|c|}
\hline \multirow{4}{*}{ Impact Factor: } & ISRA (India) & $=3.117$ & SIS (USA) & $=0.912$ & ICV (Poland) & $=6.630$ \\
\hline & ISI (Dubai, UAE & $=0.829$ & РИНЦ (Russia) & $=0.156$ & PIF (India) & $=1.940$ \\
\hline & GIF (Australia) & $=0.564$ & ESJI (KZ) & $=5.015$ & IBI (India) & $=4.260$ \\
\hline & JIF & $=1.500$ & SJIF (Morocco) & $=5.667$ & OAJI (USA) & $=0.350$ \\
\hline
\end{tabular}

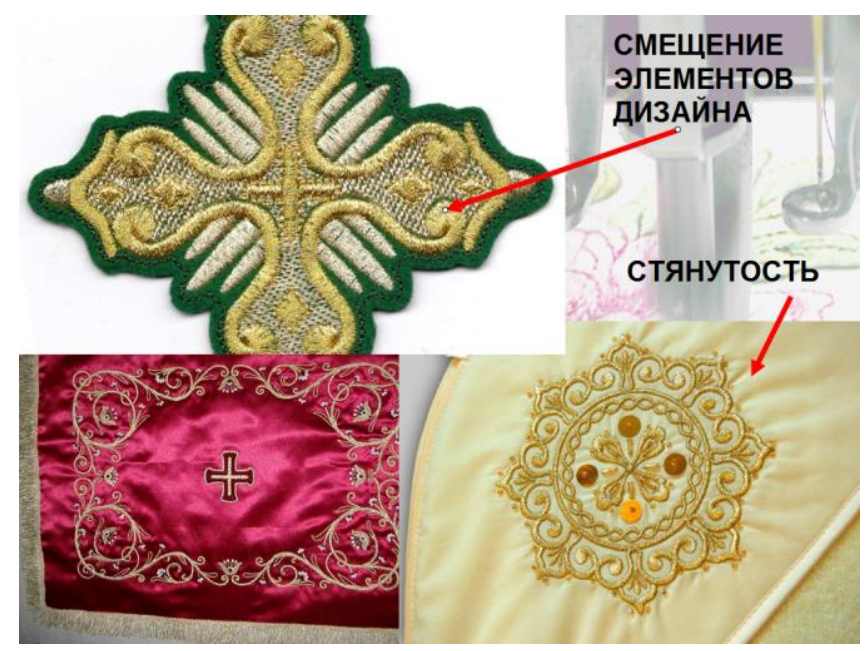

Рисунок 2. Основные дефекты машинной вышивки.

Настил служит для укрепления материалов и снижения их сморщивания и стягивания, особенно при выполнении дизайнов значительной площади. Он также обеспечивает «возвышение» вышивки, приподнимая покрывающие стежки и предотвращая их погружение в мягкие ткани. При выполнении вышивки на ворсовых материалах [7] применение настила позволяет прикрыть ворс, который может пробиваться между нитками вышивки и портить внешний вид изделия. Крупным областям и растягивающимся тканям, таким как трикотаж и пике, обычно требуется более интенсивный настил, чем небольшим областям и плотным тканям, таким как тик или кожа (рис.3).

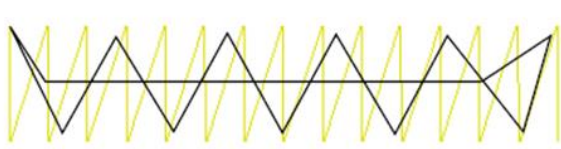

Одинарный «зиг-заг»

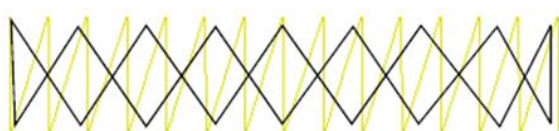

Двойной «зиг-заг»
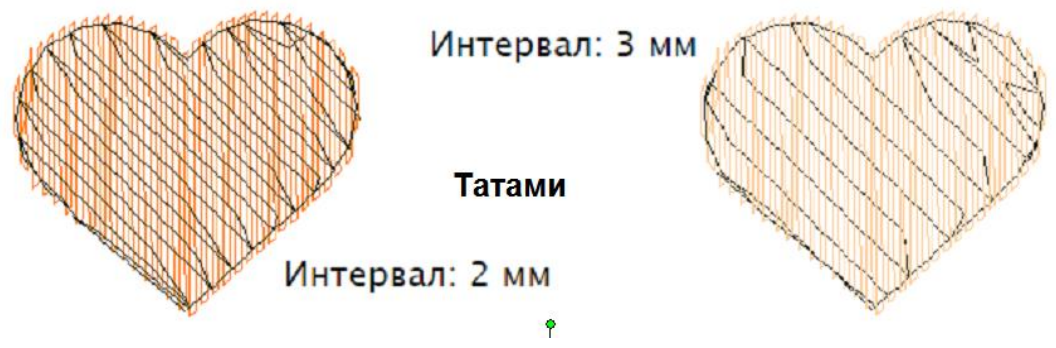

Рисунок 3. Применение настила в вышивке.

Вышивальные стежки имеют тенденцию стягивать ткань внутрь при проникновении иглы. Это может вызвать стягивание ткани и появление просветов в вышивке [8]. Автоматическая компенсация стягивания противодействует этому явлению, выполняя строчки и застилы с заданным припуском относительно контуров заполняемых форм (рис. 4). Игла проникает в материал на некотором расстоянии от контура элемента дизайна, что позволяет компенсировать эффект стянутости материала вышивальными нитями. Компенсация стягивания в программе «Urfinus» может задаваться различной по двум осям, но целиком для всего дизайна. В программе «Wilcom» компенсация задаётся одинаковой во всех направлениях, но для каждого элемента дизайна различно. 


\begin{tabular}{|c|c|c|c|c|c|c|}
\hline \multirow{4}{*}{ Impact Factor: } & ISRA (India) & $=3.117$ & SIS (USA) & $=0.912$ & ICV (Poland) & $=6.630$ \\
\hline & ISI (Dubai, UAE & $=0.829$ & РИНЦ (Russia) & $=0.156$ & PIF (India) & $=1.940$ \\
\hline & GIF (Australia) & $=0.564$ & ESJI (KZ) & $=5.015$ & IBI (India) & $=4.260$ \\
\hline & JIF & $=1.500$ & SJIF (Morocco) & $=5.667$ & OAJI (USA) & $=0.350$ \\
\hline
\end{tabular}

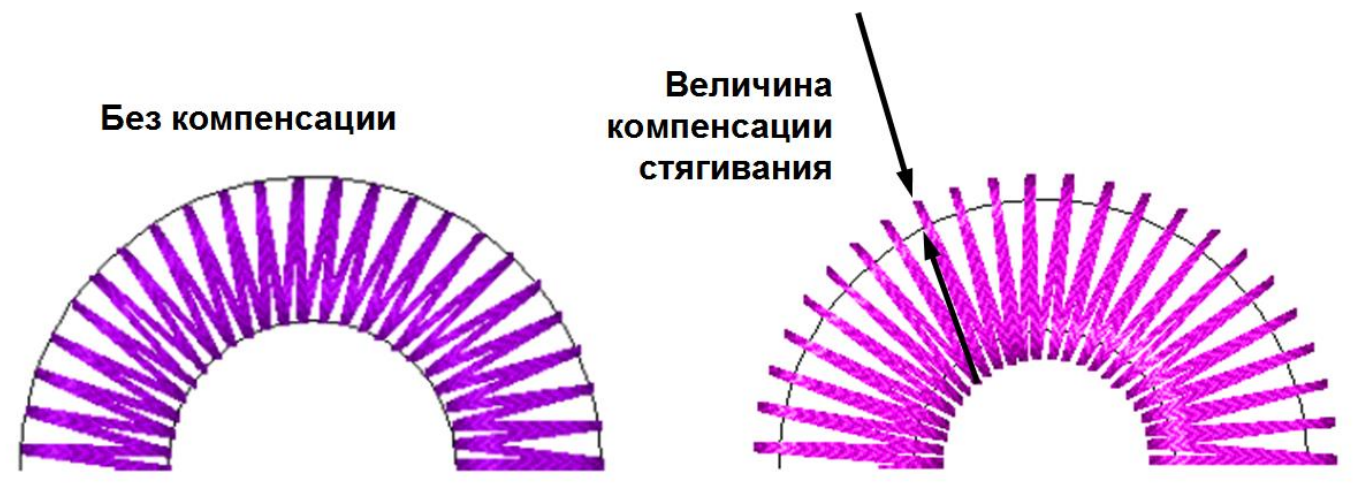

Рисунок 4. Применение компенсации стягивания.

Опытное изготовление образцов крестов и орнаментов, используемых в богослужебных предметах из текстиля, позволило разработать рекомендации по определению параметров автоматизированной вышивки в среде программы «Wilcom» (таблица 2). В качестве основы используют малоосыпаемые материалы поверхностной плотностью $150 \ldots 250$ г/м². Края крестов из осыпающихся тканей (например, атлас) обрабатывают строчкой «зиг-заг» [9]. Вышивку выполняют вышивальными металлизированными нитями №40. Натяжение нити зависит от типа вышивального оборудования. Необходимо, чтобы с лицевой стороны изделия челночная нить не выглядывала, a с изнаночной стороны соотношение челночной и игольной нитей составляло примерно 2/1...3/1 [10].

Таблица 2. Параметры вышитых отделочных элементов.

\begin{tabular}{|c|c|c|c|c|c|}
\hline 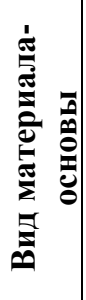 & $\begin{array}{c}\text { Наличие и вид стабилизатора } \\
\text { (флизелин, дублерин) }\end{array}$ & 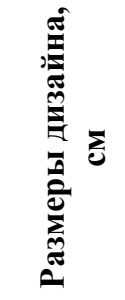 & $\begin{array}{c}\text { Вид и плотность } \\
\text { основного } \\
\text { заполнения }\end{array}$ & $\begin{array}{c}\text { Вид и плотность } \\
\text { настила }\end{array}$ & 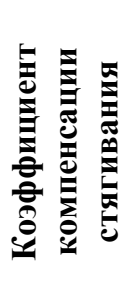 \\
\hline \multirow{4}{*}{ 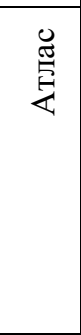 } & $\begin{array}{l}\text { дублерин трикотажный } \\
\text { тонкий+флизелин отрывной } 35 \Gamma / \mathrm{M}^{2}\end{array}$ & $20 \times 20$ & $\begin{array}{l}\text { татами } 0,37 \\
\text { сатин } 0,35\end{array}$ & \multirow{4}{*}{$\begin{array}{l}\text { строчка по центру } 2 \\
\text { мм, одинарный } \\
\text { «зиг-заг» 1,5 мм }\end{array}$} & 0,25 \\
\hline & $\begin{array}{l}\text { дублерин трикотажный } \\
\text { тонкий+флизелин отрывной } 35 \Gamma / \mathrm{M}^{2}\end{array}$ & $12 \times 12$ & $\begin{array}{l}\text { татами } 0,37 \\
\text { сатин } 0,35\end{array}$ & & 0,20 \\
\hline & $\begin{array}{l}\text { дублерин трикотажный } \\
\text { тонкий+флизелин отрывной } 35 \text { г/м² }\end{array}$ & $8 \times 8$ & $\begin{array}{l}\text { татами } 0,37 \\
\text { сатин } 0,35\end{array}$ & & 0,17 \\
\hline & $\begin{array}{l}\text { дублерин трикотажный } \\
\text { тонкий+флизелин отрывной } 35 \Gamma / \mathrm{M}^{2}\end{array}$ & $4,5 \times 4,5$ & $\begin{array}{l}\text { татами } 0,37 \\
\text { сатин } 0,35\end{array}$ & & 0,15 \\
\hline \multirow{5}{*}{$\stackrel{\mathscr{\theta}}{\mathscr{\theta}}$} & дублерин трикотажный клеевой & $12 \times 12$ & $\begin{array}{l}\text { татами } 0,4 \\
\text { сатин } 0,36\end{array}$ & \multirow{3}{*}{$\begin{array}{l}\text { татами } 2 \text { мм, } \\
\text { одинарный «зиг- } \\
\text { заг» 1,5 мм }\end{array}$} & 0,25 \\
\hline & дублерин трикотажный клеевой & $8 \times 8$ & $\begin{array}{l}\text { татами } 0,4 \\
\text { сатин } 0,36\end{array}$ & & 0,20 \\
\hline & дублерин трикотажный клеевой & $4,5 \times 4,5$ & $\begin{array}{l}\text { татами } 0,4 \\
\text { сатин } 0,36\end{array}$ & & 0,17 \\
\hline & \multirow[t]{2}{*}{$\begin{array}{l}\text { Дублерин трикотажный тонкий+ } \\
\text { отрывной флизелин клеевой }\end{array}$} & $\begin{array}{c}11,5 \times 1 \\
1,5\end{array}$ & $\begin{array}{l}\text { татами } 4 \times 0,4 \\
\text { сатин } 0,40 \\
\text { строчка стежком } \\
\text { назад иголку } 2,5 \\
\text { при кратности } 3 \\
\text { сетка } 5 \times 7 \\
\end{array}$ & $\begin{array}{l}\text { двойной «зиг-заг» } 2 \\
\text { мм под сатином }\end{array}$ & 0,25 \\
\hline & & $7,5 \times 7,5$ & сатин 0,40 & $\begin{array}{l}\text { двойной «зиг-заг» } 3 \\
\text { мм под сатином }\end{array}$ & 0,25 \\
\hline
\end{tabular}




\begin{tabular}{|c|c|c|c|c|c|c|}
\hline \multirow{4}{*}{ Impact Factor: } & ISRA (India) & $=3.117$ & SIS (USA) & $=0.912$ & ICV (Poland) & $=6.630$ \\
\hline & ISI (Dubai, UAE & $=0.829$ & РИНЦ (Russia) & $=0.156$ & PIF (India) & $=1.940$ \\
\hline & GIF (Australia) & $=0.564$ & ESJI (KZ) & $=5.015$ & IBI (India) & $=4.260$ \\
\hline & JIF & $=1.500$ & SJIF (Morocco) & $=5.667$ & OAJI (USA) & $=0.350$ \\
\hline
\end{tabular}

\begin{tabular}{|c|c|c|c|c|c|}
\hline & & $9 \times 9$ & сатин 0,35 & $\begin{array}{l}\text { двойной «зиг-заг» } 3 \\
\text { мм под сатином }\end{array}$ & 0,25 \\
\hline \multirow{4}{*}{ 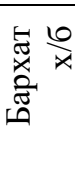 } & \multirow{4}{*}{$\begin{array}{l}\text { дублерин клеевой, водорастворимая } \\
\text { плёнка Solvi }\end{array}$} & $20 \times 20$ & \multirow{4}{*}{$\begin{array}{l}\text { татами } 0,37 \\
\text { сатин } 0,35\end{array}$} & \multirow{4}{*}{$\begin{array}{l}\text { татами } 1,5 \text { мм, } \\
\text { одинарный «зиг- } \\
\text { заг» } 1 \text { мм, строчка } \\
\text { по центру } 2 \text { мм }\end{array}$} & 0,39 \\
\hline & & $12 \times 12$ & & & 0,37 \\
\hline & & $8 \times 8$ & & & 0,32 \\
\hline & & $4,5 \times 4,5$ & & & 0,37 \\
\hline \multirow{6}{*}{ 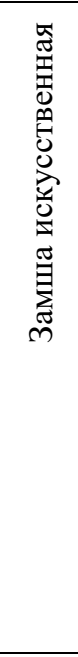 } & \multirow[t]{4}{*}{ Дублерин клеевой } & $20 \times 20$ & \multirow{4}{*}{$\begin{array}{l}\text { татами } 0,37 \\
\text { сатин } 0,35\end{array}$} & \multirow{4}{*}{$\begin{array}{l}\text { татами } 2 \text { мм, } \\
\text { одинарный «зиг- } \\
\text { заг» } 1,5 \text { мм }\end{array}$} & 0,30 \\
\hline & & $12 \times 12$ & & & 0,27 \\
\hline & & $8 \times 8$ & & & 0,22 \\
\hline & & $4,5 \times 4,5$ & & & 0,18 \\
\hline & \multirow[t]{2}{*}{$\begin{array}{l}\text { Дублерин клеевой+ толстый } \\
\text { отрывной флизелин }\end{array}$} & $12 \times 12$ & $\begin{array}{l}\text { татами } 3,5 \times 0,40 \\
\text { сатин } 0,4 \\
\text { строчка стежком } \\
\text { назад иголку } 2,5 \\
\text { при кратности } 3\end{array}$ & $\begin{array}{l}\text { двойной «зиг-заг» } 2 \\
\text { мм под сатином }\end{array}$ & $\begin{array}{c}0,20 \\
0,25 \\
0,30 \\
0,50 \\
\text { (для } \\
\text { разных } \\
\text { эл-ов) }\end{array}$ \\
\hline & & $\begin{array}{c}11,5 \times 1 \\
1,5\end{array}$ & $\begin{array}{l}\text { татами } 3 \times 0,45 \\
\text { сатин } 0,40 \\
\text { строчка стежком } \\
\text { назад иголку } 2,5 \\
\text { при кратности } 3 \\
\end{array}$ & $\begin{array}{l}\text { двойной «зиг-заг» } 2 \\
\text { мм под сатином }\end{array}$ & 0,22 \\
\hline \multirow{3}{*}{ 曾 } & \multirow{3}{*}{$\begin{array}{l}\text { Дублерин клеевой +флизелин } \\
\text { отрывной }\end{array}$} & $12 \times 12$ & \multirow{3}{*}{$\begin{array}{l}\text { татами } 0,4 \\
\text { сатин } 0,4\end{array}$} & \multirow{3}{*}{$\begin{array}{l}\text { татами } 2,5 \text { мм, } \\
\text { одинарный «зиг- } \\
\text { заг» 2,0 мм } \\
\end{array}$} & 0,25 \\
\hline & & $8 \times 8$ & & & 0,20 \\
\hline & & $4,5 \times 4,5$ & & & 0,18 \\
\hline \multirow{6}{*}{$\stackrel{\mathscr{E}}{\hat{\theta}}$} & \multirow{3}{*}{$\begin{array}{l}\text { Дублерин клеевой +флизелин } \\
\text { отрывной }\end{array}$} & $12 \times 12$ & \multirow{3}{*}{$\begin{array}{l}\text { татами } 0,37 \\
\text { сатин } 0,35\end{array}$} & \multirow{3}{*}{$\begin{array}{l}\text { татами } 1,5 \text { мм, } \\
\text { одинарный «зиг- } \\
\text { заг» } 1,5 \text { мм }\end{array}$} & 0,27 \\
\hline & & $8 \times 8$ & & & 0,22 \\
\hline & & $4,5 \times 4,5$ & & & 0,20 \\
\hline & \multirow[t]{3}{*}{$\begin{array}{l}\text { Дублерин трикотажный } \\
\text { тонкий+толстый отрывной } \\
\text { флизелин }\end{array}$} & $\begin{array}{c}4,5 \times 4,5 \\
7,5 \times 7,5 \\
9 \times 9\end{array}$ & $\begin{array}{l}\text { татами } 3 \times 0,35 \\
\text { сатин } 0,35 \\
\text { строчка стежком } \\
\text { назад иголку 2,5 } \\
\text { при кратности } 3 \\
\end{array}$ & $\begin{array}{l}\text { двойной «зиг-заг» } \\
1,5 \text { мм под сатином }\end{array}$ & 0,20 \\
\hline & & $\begin{array}{c}12,5 \times 1 \\
2,5 \\
14,5 \times 1 \\
4,5\end{array}$ & 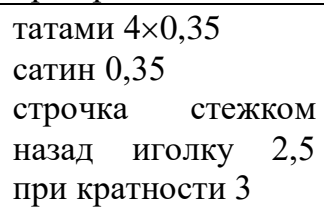 & $\begin{array}{l}\text { двойной «зиг-заг» } \\
1,5 \text { мм под сатином }\end{array}$ & 0,25 \\
\hline & & $\begin{array}{c}150 \times 15 \\
0\end{array}$ & $\begin{array}{l}\text { татами } 3 \times 0,35 \\
\text { сатин } 0,35 \\
\text { строчка стежком } \\
\text { назад иголку } 2,5 \\
\text { при кратности } 3 \\
\text { сетка } 5 \times 7\end{array}$ & $\begin{array}{l}\text { двойной «зиг-заг» } \\
1,5 \text { мм под сатином }\end{array}$ & 0,27 \\
\hline
\end{tabular}

\section{Выводы.}

Таким образом, выявлены следующие закономерности создания дизайна отделочных крестов:

- при увеличении размера вышитых элементов необходимо увеличивать значение компенсации стягивания. Для комплектов крестов она составляет $0,2 \ldots 0,3$ мм, в единичных случаях может достигать 0,5 мм;

- чем уже сатиновое заполнение, тем реже устанавливают частоту настила. При ширине сатина до 3,5 мм частота настила «зиг-заг» составляет 2...3 мм. При ширине сатина более 3,5 мм рекомендуется установить частоту настила «зиг-заг» $1,5 \ldots 2$ мм. С целью маскировки возможного пропуска стежков основного застила целесообразно применять тип нижнего настила «двойной зигзаг»;

- под застилами типа татами рекомендуется применять нижний настил татами частотой заполнения $1,5 \ldots 2$ мм, однако отсутствие настила 


\begin{tabular}{|c|c|c|c|c|c|c|}
\hline \multirow{4}{*}{ Impact Factor: } & ISRA (India) & $=3.117$ & SIS (USA) & $=0.912$ & ICV (Poland) & $=6.630$ \\
\hline & ISI (Dubai, UAE & $=0.829$ & РИНЦ (Russia) & $=0.156$ & PIF (India) & $=1.940$ \\
\hline & GIF (Australia) & $=0.564$ & ESJI (KZ) & $=5.015$ & IBI (India) & $=4.260$ \\
\hline & JIF & $=1.500$ & SJIF (Morocco) & $=5.667$ & OAJI (USA) & $=0.350$ \\
\hline
\end{tabular}

создаёт дополнительный декоративный эффект, имитирующий ручные прикрепы;

- при вышивке на бархате и искусственной замше величина компенсации стягивания должна быть на 0,05 мм больше, чем на других материалах;

- пакеты прокладочных материалов состоят из дублирующего материала (дублерины), отрывного нижнего стабилизатора (на клеевой основе или приклеенного к изнаночной стороне материала-основы, запяленной в пяльцы, ткани) и в случае тканей с ворсом применяют верхний водорастворимый плёночный стабилизатор.

Разработанные параметры можно применять при использовании различного программного обеспечения для создания автоматизированной вышивки. Изготовленные комплекты отделочных крестов для облачений соответствуют церковным традициям и сохранили свой внешний вид при проведении опытной носки в течение 1 года.

\section{References:}

1. Zolottseva, L. V., Kholodnova, Y. V., \& Parkhomenko, Y. A. (2018). Analiz zastilov $i$ strochek ruchnoy $i$ mashinnoy vyshivki dlya dekorirovaniya odezhdy $i$ golovnykh uborov [Tekst]. V kn. Innovatsionnoye razvitiye legkoy i tekstil'noy promyshlennosti: sbornik materialov Mezh-dunarodnoy nauchnoy studencheskoy konferentsii. Chast' 2. (pp.214217). M.: FGBOU VO «RGU im. A.N. Kosygina».

2. Aksenova, I. A., et al. (2015). Analiz svojstv nitok, primenyaemykh dlya stachivaniya detalej obolochek plotnogo prileganiya (tezisy). Dizajn, tekhnologii i innovatsii v tekstil'noj i legkoj promyshlennosti (INNOVATSII-2015): sbornik materialov Mezhdunarodnoj nauchnotekhnicheskoj konferentsii. Chast' 2. (pp.4-6). M.: FGBOU VPO «MGUDT».

3. (n.d.). Portal «Pravoslaviye $i$ mir». Oblacheniya svyashchennika. Retrieved January 29, 2019, from https://www.pravmir.ru/svyashhennyeoblacheniya/

4. Zolottseva, L. V., \& Kholodnova, Y. V. (2007). Sovmestnoye tvorchestvo pravoslavnogo i svetskogo vuzov po razvitiyu tserkovnogo shit'ya s uchotom kanonov i traditsiy Russkoy Pravoslavnoy Tserkvi [Tekst]. Dizayn $i$ tekhnologii, № 7 (49), 3-6.

5. (n.d.). Ikonografiya vostochno-khristianskogo iskusstva. Proyekt Nauchnogo otdela Fakul'teta tserkovnykh khudozhestv Pravoslavnogo Svyato-Tikhonovskogo gumanitarnogo universiteta. Retrieved January 29, 2019, from http://icons.pstgu.ru/needlework?page $=6 \&$ perpage $=40$

6. Kholodnova, Y. V. (2001). Razrabotka promyshlennykh metodov izgotovleniya odezhdy dukhovenstva Russkoy Pravoslavnoy Tserkvi [Tekst]: diss. ... kand. tekhn. nauk: 05.19.04: zashchishchena 19.12.2001: utv. 12.03.2002. (p.274). Moscow.

7. Demskaya, A. A., Kirsanova, E. A., Vershinina, A. V., \& Chalenko, E. A. (2016). Vliyaniye svoystv materialov i metodov tekhnologicheskoy obrabotki na formirovaniye esteticheskogo vospriyatiya shveynykh izdeliy. Dizayn i tekhnologii, № 53 (95), 51-56.

8. Chalenko, E. A. (2017). Vliyaniye tekhnologicheskoy obrabotki na svoystva materialov dlya izgotovleniya shveynykh izdeliy. V sbornike: Rezul'taty sovremennykh nauchnykh issledovaniy i razrabotok sbornik statey pobediteley II Mezhdunarodnoy nauchno-prakticheskoy konferentsii. (p.61-63).

9. Kirsanova, E. A., \& Chalenko, E. A. (2016). Modelirovaniye svoystv materialov legkoy promyshlennosti $v$ zavisimosti ot formy izdeliy. V sbornike: Aktual'nyye napravleniya fundamental'nykh i prikladnykh issledovaniy Materialy VIII mezhdunarodnoy nauchnoprakticheskoy konferentsii. (p.62-65).

10. (n.d.). Embroidery-Digitizing. Mashinnaya vyshivka. Razrabotka i tekhnologii. Voprosy $i$ otvety. Teorii i praktiki. Retrieved January 29, 2019, from http://embroiderydigitizing.ru/testiruem-natyazhenie-verxnej-inizhnej-niti-mashiny/ 